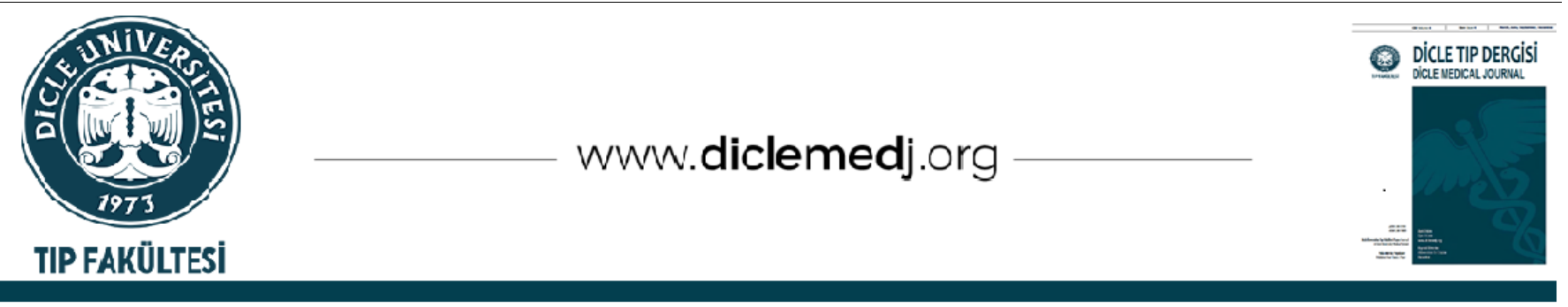

Review / Derleme

\title{
The Radiology of COVID-19 Pneumonia
}

\author{
Cihan Akgül Özmen ${ }^{(D} 1$ \\ 1 Dicle University School of Medicine Department of Radiology, Diyarbakır, Turkey \\ Received: 15.09.2021; Accepted: 29.09.2021
}

\begin{abstract}
Coronavirus disease 2019 (COVID-19) has reached a pandemic stage in March 2020 and currently more than 220 million patients worldwide are infected. The characteristic findings of COVID-19 pneumonia are bilateral, peripheral, rounded ground-glass opacities (GGO) which are dominantly located in the lower lobes and that may be accompanied by consolidation. The distribution of the parenchymal lesions was reported to be bilateral (88\%), multi-lobar (78\%) and peripheral (76\%), with a tendency to involve the posterior regions of the lungs (80\%). Several other chest CT findings, such as interlobular septal thickening, bronchiectasis, "crazy paving" and halo sign, have also been reported but with a lower frequency.

RSNA has published consensus statements to reduce report variability among radiologists and defined 4 main categories: typical, indeterminate, atypical, and negative, to provide a relative likelihood that these findings are attributable to COVID-19 pneumonia.

It is vital to understand that imaging may be normal in the early stages of COVID-19, and many conditions may present with imaging findings mimicking COVID-19 pneumonia. Chest CT may be also used as a useful tool for better identification of patients who will benefit from more aggressive therapy. In addition, CT may be used to evaluate patency of pulmonary and coronary vascular structures and myocardial damage.

Although CT scan is not recommended as a diagnostic and screening tool, it can be helpful to clinician for a fast and accurate decision-making and has a crucial role in the diagnosis, risk stratifying, and follow-up of the progression of COVID-19 pneumonia.
\end{abstract}

Keyword: COVID-19, pneumonia, chest CT

DOI: 10.5798/dicletip.1004017

Correspondence / Yazışma Adresi: Cihan Akgül Özmen, Dicle University School of Medicine Department of Radiology, 21180 Diyarbakır, Turkeye-mail: cihanakgul@gmail.com 


\section{COVID-19 Pnömonisinde Radyoloji}

Öz

Korona virüs hastalı̆̆ (COVID-19) Mart 2020 itibariyle pandemi olarak kabul edildi ve dünya çapında yaklaşık 220 milyondan fazla insan infekte oldu. Radyolojik bulgular bilateral periferik, ağırlıklı olarak alt loblarda yerleşim gösteren yuvarlak buzlu cam alanları ve eşlik edebilen konsolidasyon alanları ile karakterizedir. Parankimal lezyonların dağılımı bilateral (\%88), multilobar (\%78), ve periferik (\%76) olarak bildirilmiş olup, akciğerlerin arka alanlarını tutma eğilimindedir. Diğer bilgisayarlı tomografi (BT) bulguları arasında interlobuler septal kalınlaşma, bronşektazi, Arnavut kaldırımı görünümü, halo bulgusu ve ters halo görünümü sayılabilir.

RSNA, radyologlar arası raporlama farklılıklarını azaltmak amacıyla bir uzlaşı bildirisi yayınladı ve radyolojik bulguları COVID-19 pnömonisine benzerliği açısından tipik, belirsiz, atipik ve negatif olmak üzere 4 gruba ayırdı.

Görüntülemenin başlangıç evresinde görüntülemnin normal olabileceğini, ayrıca bulguların pek çok başka hastalığın benzer bulgular göstereceğini bilmek oldukça önemlidir. Toraks BT, daha agresif tedaviden fayda görecek hasta grubunu belirlemede önemlidir. Ek olarak pulmoner ve koroner vasküler yatak açıklığı, myokard hasarı gibi diğer bulguları ortaya koymada değerlidir.

COVID-19 pnömonisinde, BT rutin tarama için önerilmese de klinisyenin hızlı karar vermesine yardımcı ve tanı, risk sinıflandırması ve hastalık progresyonunun takibinde kritik öneme sahiptir.

Anahtar kelimeler: COVID-19, pnömoni, Toraks BT.

\section{INTRODUCTION}

Coronavirus disease 2019 (COVID-19), caused by severe acute respiratory syndrome coronavirus 2 (SARS-CoV2), has become increasingly prevalent worldwide, reaching a pandemic stage in March 2020. After that more than 220 million patients worldwide by September 2021 were reported to be infected ${ }^{1}$. The American College of Radiology and the Society of Thoracic Radiology do not recommend chest computed tomography (CT) for screening or diagnosis of COVID-192. In addition, World Health Organization (WHO) consensus guidelines, recommend to use of reverse-transcription polymerase chain reaction (RT-PCR) over chest imaging for the diagnosis of COVID-193. However, a low sensitivity of 60-70\% for the gold standard RTPCR test ${ }^{4}$ and barriers to access the test has left a large area to Chest CT for diagnosis of COVID19 in this pandemic.

\section{Indications for Imaging}

The indications for imaging in COVID-19 have evolved since the first diagnosis in China.
Although in early period of the disease some Chinese authors suggested routine diagnostic CT imaging in patients' with probable COVID19 pneumonia, medical societies in the United States and Europe, recommended a more conservative approach ${ }^{5}$. Finally, the precise role of imaging in COVID-19 pneumonia remains somewhat arguable and varies according resources, and preferences of health authorities.

The Fleischner Society published a multinational consensus paper to guide on the use of imaging modalities in COVID-19 pneumonia ${ }^{6}$. They recommended to not use routine imaging as a screening test for COVID19 in asymptomatic individuals, and stated no indication for daily chest X-ray in stable intubated patients. CT was suggested solely in patients with functional impairment, hypoxemia, or both after recovery from COVID19 infection. The American College of Radiology and World Health Organization also do not recommend the use of routine chest imaging for the diagnosis of COVID-192,3. 


\section{Chest radiograph}

Although, chest radiograph is widely used in radiology practice of chest diseases, it is not routinely recommended in pandemic clinical practice because of insensitivity in detecting lesions of COVID-19 in the early stages. However, chest radiography may have some utility, such as a screening tool on the frontlines in areas with limited resources or in cases where the patient's physical condition does not allow transporting to the radiology department for CT scanning. In later stages of the disease, chest $\mathrm{x}$-ray can detect multiple patchy opacities which eventually become confluent and severe cases may appear as a "white lung"7,8.

\section{Chest CT}

The first report describing the chest CT findings in 41 patients with confirmed COVID-19 was published in February $2020^{9}$. After that, the scientific evidence on COVID-19 has been rapidly growing and the role of chest $\mathrm{CT}$ is continuously evolving. CT has been used in diagnosis, staging, determination of severity, and progression of the disease.

\section{CT Findings of COVID-19 pneumonia}

The radiology literature has successfully reported the characteristic findings of COVID19 pneumonia, which most commonly include bilateral, peripheral, rounded ground-glass opacities (GGO) which are dominantly located in the lower lobes and that may be accompanied by consolidation ${ }^{10}$.

The distribution of the parenchymal lesions was reported to be bilateral (88\%), multi-lobar $(78 \%)$ and peripheral $(76 \%)$, with a tendency to involve the posterior regions of the lungs $(80 \%)^{11}$. Several other chest CT findings, such as interlobular septal thickening, bronchiectasis, "crazy paving" and halo sign, have also been reported but with a lower frequency11,12. However, pleural and pericardial effusions, mediastinal lymphadenopathy and pulmonary nodules have been rarely reported ${ }^{11}$.

\section{Peripheral GGo}

The lung area with the increased lung opacity without obscuring bronchovascular markings is defined as GGO (13) (Figure 1). It is the most common reported imaging finding of COVID-19 pneumonia (40-83\%). Posterior areas of lower lobes are most commonly involved regions of lung. However, COVID-19 pneumonia may start as unilateral GGO then progress to diffuse, bilateral disease ${ }^{14}$.

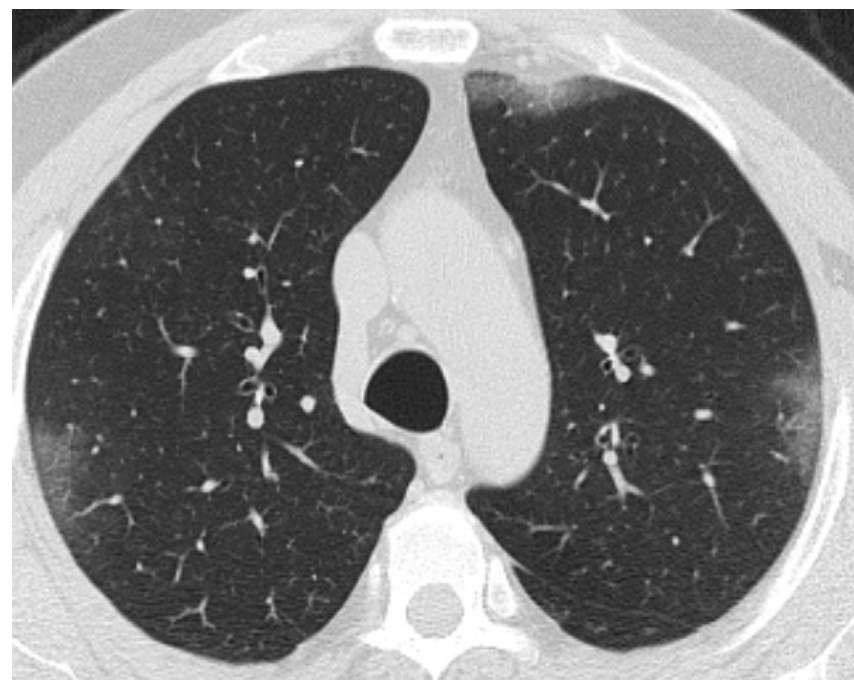

Figure 1: Bilateral multifocal peripherally ground glass opacities are seen.

\section{Crazy paving pattern}

Crazy paving refers to the appearance of diffuse ground-glass attenuation with superimposed interlobular septal thickening and intralobular septal thickening on CT images ${ }^{15}$. It has been reported in 5-36\% of patients with COVID-19 pneumonia ${ }^{16}$ (Figure 2). Crazy paving pattern may be accepted as a marker of disease progress or it may be recognized at peak of the disease ${ }^{17}$. 


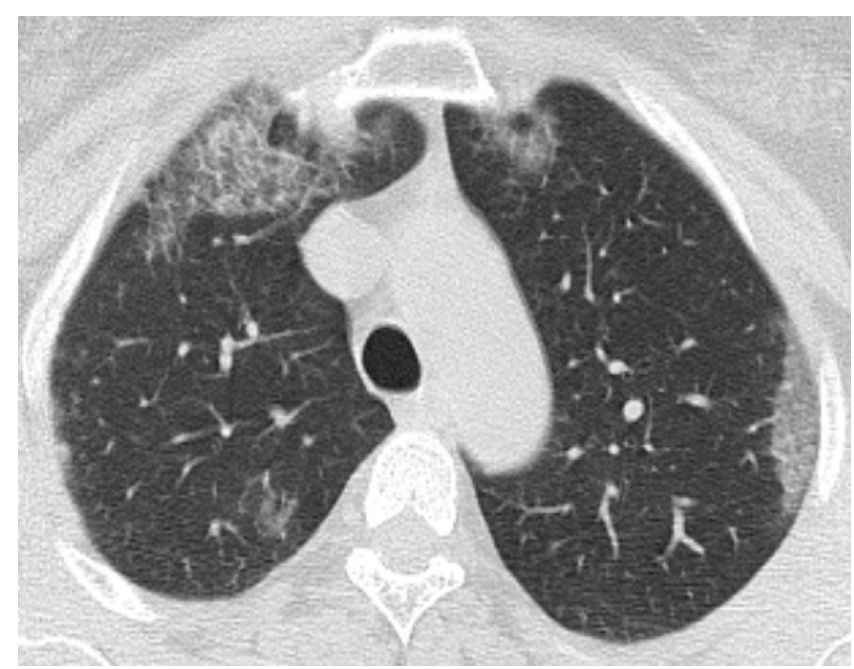

Figure 2: Bilateral ground glass opacities and superimposed interlobular septal thickening (crazy paving pattern)

\section{Reversed halo appearance}

Reversed halo sign (also called as the Atoll sign) is defined as a round/ovoid ground-glass attenuation with complete or crescent ring of consolidation at its periphery ${ }^{13}$. It has been reported in $11.1 \%$ of COVID-19 literature ${ }^{18,19}$ (figure 3). Moreover, it may be accepted as maker of disease progression, resulting consolidation around GGO or lesion absorption with the consequent decreased central density ${ }^{19}$.

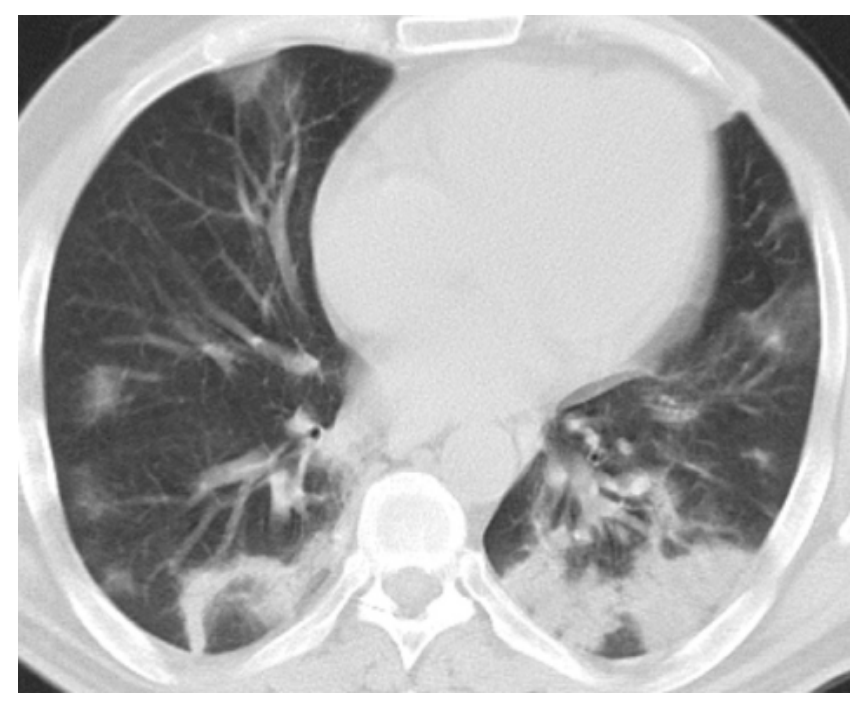

Figure 3: Reversed halo sign is seen in the right lower lobe. In addition, bilateral ground glass opacities and left lower lobe consolidation are observed.

\section{Findings of organizing pneumonia}

Organizing pneumonia is a non-infectious inflammatory pulmonary condition that classically appears as a nodular or mass-like consolidation with predilection to peribronchovascular and subpleural areas. These lesions are more severe in the lower lobes $^{13}$. Reversed halo sign is highly suggestive for diagnosis of $\mathrm{OP}^{13}$ (Figure 4). Organizing pneumonia not specific to COVID-19 and may also be secondary to the connective tissue disease, drug toxicity, infection, immunologic disorders, toxic inhalation, and graft versus host disease ${ }^{19}$.

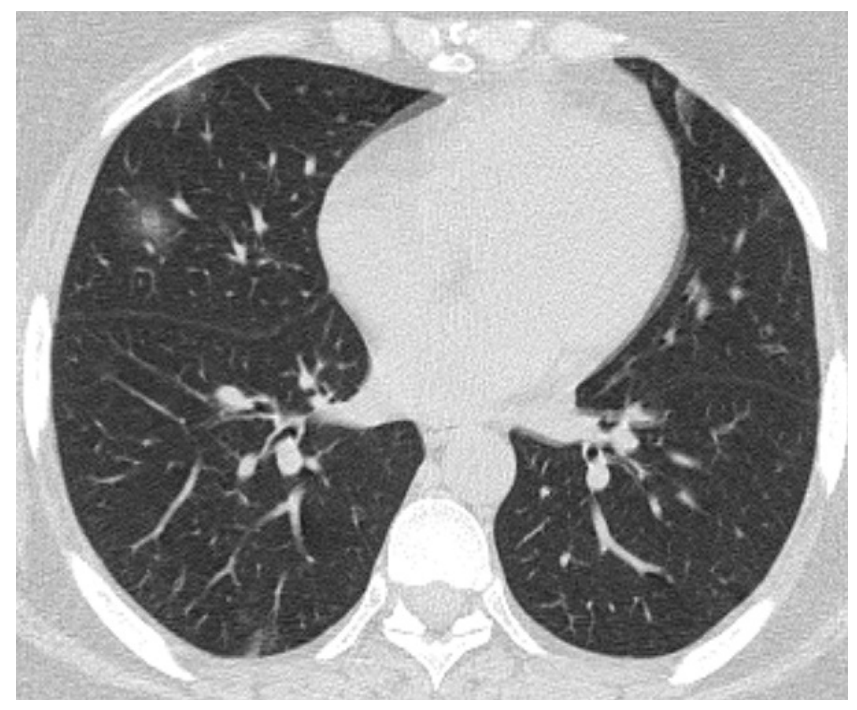

Figure 4: A solid nodül in the right middle lobe with peripheral ground glass opacity (halo sign)

\section{Halo sign}

Halo sign is defined as a condition in which central nodule or consolidations surrounded by ground-glass opacities. This sign has been reported in up to one - third in some series of COVID-19 disease ${ }^{18,19}$ (Figure 5). However, the main pathological stimulus of this manifestation still remains unknown. 


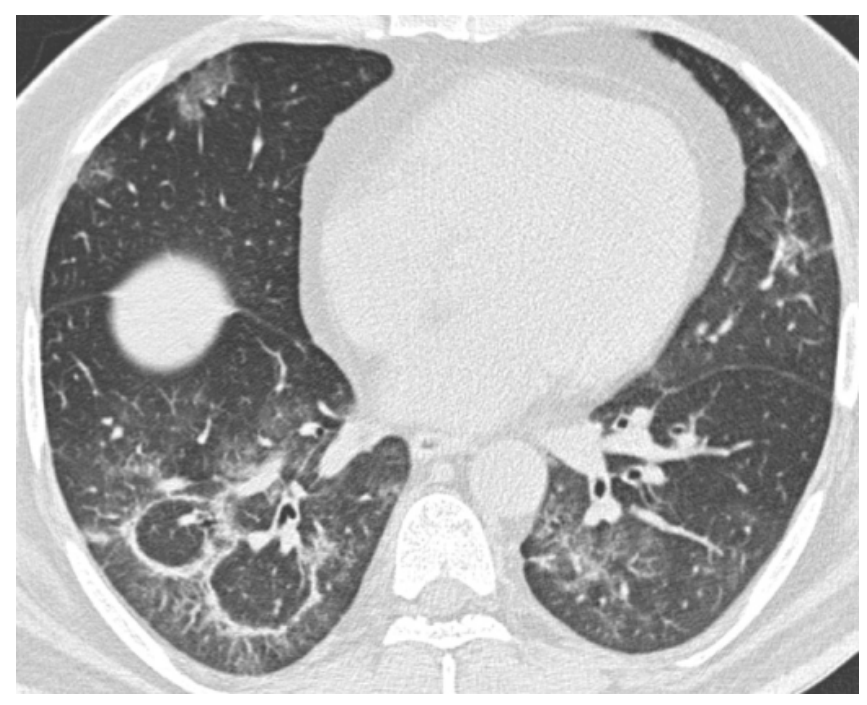

Figure 5: Consolidation areas in form of reversed halo represents organizing pneumonia in right lower lobe. Also bilateral ground glass opacities are present.

\section{Consolidation}

It refers to area of the increased opacity obscuring underlying bronchovascular lines ${ }^{13}$. Multifocal and patchy distributed consolidation in subpleural and peribronchovascular regions has been reported in $2-64 \%$ of cases infected with COVID-19 pneumonia18,19 (Figure 6). In those older than 50 years age, or with longer time duration of the disease before CT scan acqusition, may have a more consolidative appearance ${ }^{20}$. Unilateral lesions can also be observed, especially in early period and in asymptomatic patients or minimal symptoms. Accordingly, unilateral lesion were reported in $18.7 \%$ of cases in a meta-analysis of 4121 patients $^{21}$.

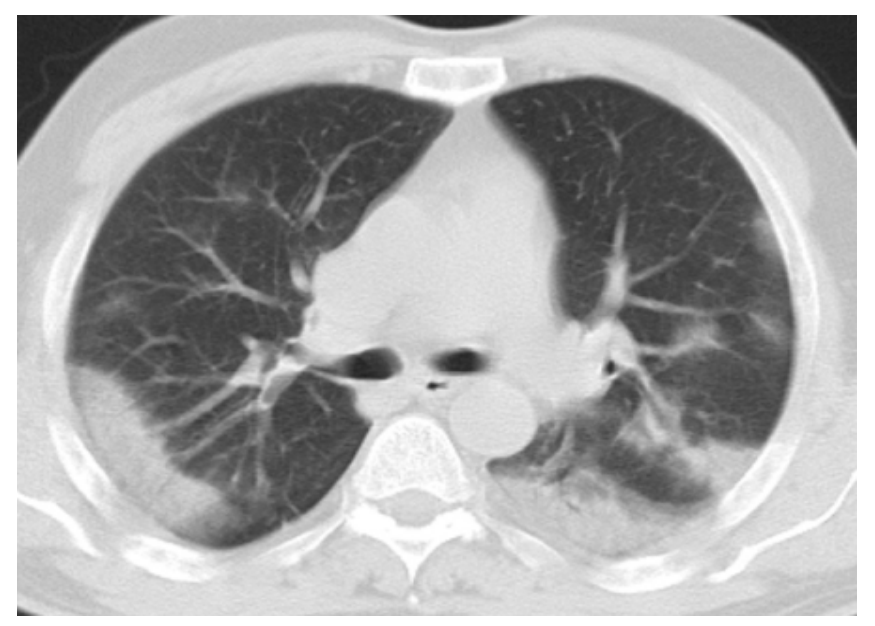

Figure 6: Peripheral and posteriorly located multifocal consolidations are seen in both lungs.

\section{Diagnosis of the disease}

The sensitivity and specificity of CT varies widely, and there are many limitations. Values from individual patient cohorts ranged between $61 \%$ and $99 \% 22$. Only few studies reported the specificity of CT in the diagnosis of COVID-19, with values ranging between $24 \%$ and $94 \%{ }^{22}$.

Extreme caution must be taken when ruling-out COVID-19 disease on the basis of a negative CT scan. Indeed, false negative CT scans may be encountered, especially when performed within first two days. Bernheim et al. ${ }^{23}$ reported that normal CT findings were observed for $56 \%, 9 \%$, and $4 \%$ of patients at 0 $2,3-5$, and 6-12 days after onset of symptom, respectively. High variable results from diagnostic studies may be stemmed from low reliability of RT-PCR in different conditions, timing of sampling and patients and low specificity of CT signs of COVID-19 pneumonia.

\section{CT structured reporting proposals}

The Radiological Society of North America (RSNA) has recently published an expert consensus statement to reduce report variability among radiologists and to be helpful in the management of patients with COVID-19 (Table 1) ${ }^{24}$. In this consensus statement, imaging findings are divided into 4 main categories: typical, indeterminate, atypical, and negative, to provide a relative likelihood that these findings are attributable to COVID-19 pneumonia.

It is vital to understand that imaging may be normal in the early stages of COVID-19, and that many conditions may present with imaging findings mimicking those that have been reported in COVID-19 pneumonia. 
Table I: RSNA Chest CT Classification Sysytem for Reporting COVIT-19 Pneumonia

\begin{tabular}{|c|c|c|}
\hline $\begin{array}{l}\text { COVID-19 Preumonia Imag- } \\
\text { ing Classificarion }\end{array}$ & Rarionale & CT Findings \\
\hline Typical appearance & $\begin{array}{l}\text { Commonly reported imaging } \\
\text { feacures of greater specificity } \\
\text { for COVID-19 pneumonia }\end{array}$ & $\begin{array}{l}\text { Peripheral, bilateral, GGO with or without } \\
\text { consolidation or visible intralobular lines } \\
\text { ("erazy-paving") } \\
\text { Mulcifocal C;C;O of rounded morphology } \\
\text { wirh or without consolidation or visible } \\
\text { intralobular lines ("erazy-paving") } \\
\text { Reverse halo sign or cother findings of organiz- } \\
\text { ing preumonia (seen later in the disease) }\end{array}$ \\
\hline Indeterminate appearance & $\begin{array}{l}\text { Nonspecific imaging fearures of } \\
\text { COVTD-19 pncumonia }\end{array}$ & $\begin{array}{l}\text { Absence of rypical features AND presence of: } \\
\text { Multifocal, diffuse, perihilar, or unilat- } \\
\text { eral GGO with or without consolidation } \\
\text { lacking a specific distribution and are } \\
\text { nonrounded or nonperipheral } \\
\text { Few, very small GGOS with a non rounded } \\
\text { and nonperipheral distribueton }\end{array}$ \\
\hline Arypical appearance & $\begin{array}{l}\text { Unoommonly or not neported } \\
\text { features of COVID-19 } \\
\text { paeumonia }\end{array}$ & $\begin{array}{l}\text { Absence of rypical or indeterminate features } \\
\text { AND presence of: } \\
\text { Isolaced lobar or segmencal consolictation } \\
\text { wirhour GGOS } \\
\text { Discrete small nodules (centrilobular, "tree- } \\
\text { in-bud") } \\
\text { Lung cavitation } \\
\text { Smoch interlobular septal thickening with } \\
\text { pleural effusion }\end{array}$ \\
\hline Negarive for pneumonia & No fearures of pneumonia & No CT fearures ro suggest pneumonia \\
\hline
\end{tabular}

In addition to RSNA various classification systems are proposed such as CO-RADS, COVID-RADS, BTSI classification.

Table II: CO-RADS 25

\begin{tabular}{|l|l|l|}
\hline CT findings & Grade & Level of suspicion \\
\hline $\begin{array}{l}\text { Scan technically insufficient for } \\
\text { assigning a score }\end{array}$ & 0 & Not interpretable \\
\hline Normal or non-infectious & 1 & Very low \\
\hline $\begin{array}{l}\text { Typical for other infection but not } \\
\text { COVID-19 }\end{array}$ & 2 & Low \\
\hline $\begin{array}{l}\text { Features compatible with COVID-19 } \\
\text { but also other diseases }\end{array}$ & 3 & Equivocal/unsure \\
\hline Suspicious for COVID-19 & 4 & High \\
\hline Typical for COVID-19 & 5 & Very high \\
\hline RT-PCR positive for SARS-CoV-2 & 6 & Proven \\
\hline
\end{tabular}

Table III: COVID-RADS 26

\begin{tabular}{|l|l|l|}
\hline CT findings & Grade & Level of suspicion \\
\hline Atypical findings & 1 & Low \\
\hline Fairly typical findings & $2 \mathrm{~A}$ & Moderate \\
\hline $\begin{array}{l}\text { Combination of atypical } \\
\text { with typical-fairly typical } \\
\text { findings }\end{array}$ & $2 \mathrm{~B}$ & Moderate \\
\hline Typical findings & 3 & High \\
\hline
\end{tabular}

Table IV: Guidance document of the BTSI ${ }^{27}$

\begin{tabular}{|c|c|}
\hline Disease pattern & Imaging appearance \\
\hline $\begin{array}{l}\text { Typical or classical } \\
\text { (near } \\
\text { confidence) } *\end{array}$ & $\begin{array}{l}\text { Lower lobe and peripheral predominant, } \\
\text { bilateral, multifocal, round, GGO With or } \\
\text { without: } \\
\text { - Reticular interstitial thickening (crazy } \\
\text { paving) } \\
\text { - Reverse Halo (Organizing pneumonia) } \\
\text { - Peripheral Consolidation }\end{array}$ \\
\hline $\begin{array}{l}\text { Probable }(71-99 \% \\
\text { confidence })^{*}\end{array}$ & $\begin{array}{l}\text { Lower lobe predominant peripheral } \\
\text { consolidation with: } \\
\text { - Bronchocentric disease } \\
\text { - Less GGO } \\
\text { - Reverse Halo (Organizing pneumonia) }\end{array}$ \\
\hline $\begin{array}{l}\text { Indeterminate } \\
(<70 \% \text { confidence })\end{array}$ & $\begin{array}{l}\text { Typical or probable imaging pattern } \\
\text { without clinical suspicion Disease pattern } \\
\text { that doesn't fit into typical or probable }\end{array}$ \\
\hline $\begin{array}{lr}\text { Atypical } & (70 \% \\
\text { confidence } & \text { for } \\
\text { alternative } & \\
\text { diagnosis }) & \end{array}$ & $\begin{array}{l}\text { - Lobar consolidation } \\
\text { - Tree-in-bud or centrilobular nodules } \\
\text { - Cavitary lesions } \\
\text { - Lymphadenopathy or effusions }\end{array}$ \\
\hline
\end{tabular}




\section{Findings of disease progression}

In particular, Pan et al. ${ }^{17}$ reported four different stages of the disease according to the time from beginning of symptoms.

Table V: Different stages of the disease progression

\begin{tabular}{|l|l|}
\hline Time period & CT Findings \\
\hline $\begin{array}{l}\text { The early phase (0-4 } \\
\text { days) }\end{array}$ & GGOs \\
\hline $\begin{array}{l}\text { The progressive } \\
\text { phase (5-8 days) }\end{array}$ & $\begin{array}{l}\text { transformation of GGOs into multifocal, } \\
\text { consolidative areas and the } \\
\text { development of a "crazy-paving" } \\
\text { pattern. }\end{array}$ \\
\hline $\begin{array}{l}\text { The peak stage (9- } \\
13 \text { days }\end{array}$ & $\begin{array}{l}\text { more extensive pulmonary involvement } \\
\text { and dense consolidations }\end{array}$ \\
\hline $\begin{array}{l}\text { The absorption stage } \\
\text { (>14 days) }\end{array}$ & $\begin{array}{l}\text { reabsorbed consolidations and } \\
\text { appearance of repaired lung signs, such } \\
\text { as fibrotic bands }\end{array}$ \\
\hline
\end{tabular}

In a similar longitudinal study, Wang et al.28 also confirmed that pure GGOs were the most common CT findings after symptom onset whereas the prevalence of a mixed pattern of GGOs and irregular linear opacities peaked at 6-11 days. Lung abnormalities usually persist for a long time on chest imaging

In "Expert Recommendations from the Chinese Medical Association Radiology Branch," chest CT findings of COVID-19 are similarly divided into three stages: early, advanced, and severe based on the extent of lesion involvement ${ }^{8}$. In the early phase, the patients have moderate clinical manifestations of the disease, and CT lesions are limited to single or multiple areas commonly at subpleural areas or bronchial areas. In the progressive phase, most of the lesions progressed rapidly, move parallel to the severe clinical disease. In the severe phase of COVID-19, the lung lesions generally peaked at 14 days after the symptoms, but a few cases rapidly progresses leading bilaterally with diffuse infiltration of all of the lung, and manifesting as "white lung." The dissipative phase was seen most commonly after 14 days after the symptoms. The gradual absorption of the lesions, progress to fibrotic cord-like highdensity shadows.

\section{Extent of pulmonary involvement}

Several semi-quantitative scores have been developed in radiology literature to evaluate the extent of pulmonary involvement and to objectively monitor the course of the disease.

Pan et al. ${ }^{17}$ visually scored the involvement of each of the five lung lobes as follows: 0 , indicating no involvement; 1 , less than $5 \% ; 2$, $5-25 \% ; 3,26-49 \% ; 4,50-75 \%$; and 5, 75$100 \%$. They report that the total CT score progressively increased until 10 days after symptoms with a median peak score of 6 .

\section{Differential diagnosis of radiologic findings of COVID-19 Pneumonia}

The CT appearance of COVID-19 pneumonia shares some similarities with other diseases ${ }^{7}$.

Typical findings: Common conditions with similar imaging features with those that are typical of COVID-19 include other viral pneumonias, chronic eosinophilic pneumonia (CEP), and disease processes that result in an organizing pneumonia pattern of pulmonary injury

Indeterminate category: including diffuse, multifocal, perihilar or unilateral GGO, with or without consolidation, and lacking a specific distribution pattern are imaging findings of this stage of the disease. In addition, few very small nonrounded and nonperipheral GGO are defined in this category ${ }^{24}$. These imaging findings have also been described in hypersensitivity pneumonitis, pneumocystis pneumonia (PCP), diffuse alveolar hemorrhage (DAH), pulmonary edema, and pulmonary alveolar proteinosis (PAP), which may present a diagnostic challenge in COVID19 radiology.

Atypical imaging findings of COVID-19 are findings that are rarely reported with the disease and accepted as sign of other lung disease. Atypical CT findings may include 
isolated lobar or segmental consolidation without GGO, discrete nodules (tree-in-bud or centrilobular nodules), cavitation, and pleural effusion. These findings are more commonly detected in bacterial pneumonia, some forms of community-acquired pneumonias, and aspiration pneumonia ${ }^{29}$.

\section{CT findings and disease severity}

Chest CT may provide information beyond the diagnostic utility. It may be used as a useful tool for better identification of patients who will benefit from more aggressive therapy and close monitoring. Unfortunately, only limited evidence is available on the role of imaging findings in prognosis of patients with COVID19. It has been reported that non-survivors and patients admitted to the intensive care unit (ICU) had significantly more consolidation, airbronchograms, "crazy-paving" and central involvement of the lungs compared to other hospitalized patients with COVID 1930. The most common imaging finding is consolidation rather than GGO, with an extensive lung involvement characterized by a bilateral and multilobar distribution in clinically severe patients ${ }^{31}$.

Li et al. ${ }^{32}$ and Yang et al. ${ }^{33}$ evaluated the performance of a semi-quantitative score calculating the extent of lung opacification as a marker for disease severity. The CT-score of the patients group with severe disease was significantly higher compared to the group of patients with mild symptoms. Colombi et al. ${ }^{34}$ investigated the association between the percentage of well-aerated lung (WAL) as a marker of residual respiratory function and a composite end-point of admission to ICU and death in 236 patients with COVID-19. They found that the percentage of WAL was an independent predictor of ICU admission/death after adjusting for age and other clinical risk factors.
In addition to the evaluation of lung parenchyma, CT may be used to evaluate patency of pulmonary and coronary vascular structures and myocardial damage ${ }^{22}$.

\section{CONCLUSION}

The COVID-19 pneumonia is characterized bilateral, peripheral, rounded GGO which are dominantly located in the posterior of lower lobes and that may be accompanied by consolidation. The imaging features in this pneumonia showed a broad spectrum, which indicate a wide differential diagnosis including various infectious and non-infectious causatives. Although CT scan is not recommended as a diagnostic and screening tool, it can be helpful to clinician for a fast and accurate decision-making. The radiology literature demonstrated that Chest CT has an important role in the diagnosis, risk stratifying, and follow-up of the progression of COVID-19 pneumonia.

Conflict of Interest: The authors declared no conflicts of interest.

Financial Disclosure: The authors declared that this study has received no financial support.

\section{REFERENCES}

1. Coronavirus Cases." Worldometer. Available at https://www.worldometers.info/coronavirus/Acc essed September 9, 2020.

\section{American College of Radiology (ACR).}

Recommendations for the use of chest radiography and computed tomography (CT) for suspected COVID-19 infection. Available at: https://www. acr.org/Advocacy-and-Economics/ACR-Position-

Statements/ Recommendations-for-ChestRadiography-and-CT-for-Suspected COVID19Infection. Accessed March 22, 2020.

3. Akl EA, Blazic I, Yaacoub S, et al. Use of Chest Imaging in the Diagnosis and Management of COVID-19: A WHO Rapid Advice Guide. Radiology. 2021; 298: E63-E69. 
4. Rubin EJ, Baden LR, Morrissey S, Campion EW. Medical Journals and the 2019-nCoV Outbreak. N Engl J Med. 2020; 382: 866.

5. Sharma A, Eisen JE, Shepard JO, Bernheim A, Little BP. Case 25-2020: a 47-year-old woman with a lung mass. N Engl J Med 2020; 383: 665-74.

6. Rubin GD, Ryerson CJ, Haramati LB, et al. The role of chest imaging in patient management during the COVID-19 pandemic: a multinational consensus statement from the Fleischner Society. Radiology 2020; 296: 172-80.

7. Yang, $W$, Sirajuddin, A, Zhang, X. et al. The role of imaging in 2019 novel coronavirus pneumonia (COVID-19). Eur Radiol 2020; 30: 4874-82.

8. Chinese Medical Association Radiology Branch. Radiological diagnosis of new coronavirus pneumonia: expert recommendations from the Chinese Medical Association Radiology Branch (first edition). Chin J Radiol. 2020; 54: E001-E001

9. Huang C, Wang Y, Li X, et al. Clinical features of patients infected with 2019 novel coronavirus in Wuhan, China. Lancet. 2020; 395: 497-506.

10. Raptis CA, Hammer MM, Short RG, et al. Chest CT and Coronavirus Disease (COVID-19): A Critical Review of the Literature to Date. AJR Am J Roentgenol. 2020; 215: 839-42.

11. Salehi S, Abedi A, Balakrishnan S, Gholamrezanezhad A. Coronavirus disease 2019 (COVID-19): A systematic review of imaging findings in 919 patients. AJR Am J Roentgenol. 2020; 215: 87-93.

12. Ye Z, Zhang Y, Wang Y, Huang Z, Song B. Chest CT manifestations of new coronavirus disease 2019 (COVID-19): A pictorial review. Eur Radiol. 2020; 30: 4381-9.

13. Brett M. Elicker, Richard Webb. Fundamentals of high-resolution of lung CT. 2013

14. Bayraktaroğlu S, Çinkooğlu A, Ceylan N, Savaş R. The novel coronavirus pneumonia (COVID-19): a pictorial review of chest CT features. Diagn Interv Radiol. 2021; 27: 188-94.

15. Rossi SE, Erasmus JJ, Volpacchio M, et al. "Crazypaving" pattern at thin-section CT of the lungs: radiologic-pathologic overview. Radiographics. 2003; 23: 1509-19.

16. Li K, Wu J, Wu F, et al. The Clinical and Chest CT Features Associated With Severe and Critical COVID-19 Pneumonia. Invest Radiol. 2020 Jun; 55: 327-31.

17. Pan F, Ye T, Sun $P$, et al. Time course of lung changes at chest CT during recovery from coronavirus disease 2019 (COVID-19). Radiology. 2020; 295: 715-21.

18. Adams HJA, Kwee TC, Yakar D, Hope MD, Kwee RM. Chest CT Imaging Signature of Coronavirus Disease 2019 Infection: In Pursuit of the Scientific Evidence. Chest. 2020; 158: 1885-95.

19. Kwee TC, Kwee RM. Chest CT in COVID-19: What the Radiologist Needs to Know. Radiographics. 2020; 40: 1848-65.

20. Song F, Shi N, Shan F, et al. Emerging 2019 Novel Coronavirus (2019-nCoV) Pneumonia. Radiology. 2020; 297.

21. Zhu J., Zhong Z., Li H. CT imaging features of 4121 patients with COVID-19: a meta-analysis. J. Med. Virol. 2020; 92: 891-902.

22. Pontone G, Scafuri S, Mancini ME, et al. Role of computed tomography in COVID-19. J Cardiovasc Comput Tomogr. 2021; 15: 27-36.

23. Bernheim A, Mei X, Huang $M$, et al. Chest CT Findings in Coronavirus Disease-19 (COVID-19): Relationship to Duration of Infection. Radiology. 2020 Jun; 295: 200463.

24. Simpson S, Kay FU, Abbara S, et al. Radiological Society of North America Expert Consensus Statement on Reporting Chest CT Findings Related to COVID-19. Endorsed by the Society of Thoracic Radiology, the American College of Radiology, and RSNA - Secondary Publication. J Thorac Imaging. 2020 Jul;35:219-27.

25. Prokop M, van Everdingen W, van Rees Vellinga T, et al. CO-RADS: A categorical CT assessment scheme for patients suspected of having COVID-19definition and evaluation. Radiology. 2020; 296: E97-E104.

26. Salehi S, Abedi A, Balakrishnan S, Gholamrezanezhad A. Coronavirus disease 2019 
(COVID-19) imaging reporting and data system (COVID-RADS) and common lexicon: a proposal based on the imaging data of 37 studies. Eur Radiol. 2020;30: 4930-42.

27. British Society of thoracic imaging. Thoracic imaging in COVID-19 infection. Accessed August $1 \mathrm{st}$, 2021 at https://www.bsti.org.uk/media/resources/files/B STI_COVID-

19_Radiology_Guidance_version_2_16.03.20.pdf

28. Wang Y, Dong C, Hu Y, et al. Temporal changes of CT findings in 90 patients with COVID-19 pneumonia: A longitudinal study. Radiology. 2020; 296: E55-E64.

29. Hanfi SH, Lalani TK, Saghir A, McIntosh LJ, Lo HS, Kotecha HM. COVID-19 and its Mimics: What the Radiologist Needs to Know. J Thorac Imaging. 2021; 36: W1-W10.

30. Tabatabaei SMH, Talari H, Moghaddas F, Rajebi H. CT Features and Short-term Prognosis of COVID-
19 Pneumonia: A Single-Center Study from Kashan, Iran. Radiol Cardiothorac Imaging. 2020; 20; 2: e200130.

31. Minhua Yu DX, Lan Lan, Tu Mengqi, et al. Thinsection chest CT imaging of coronavirus disease 2019 pneumonia: comparison between patients with mild and severe disease. Radiol: Cardiothoracic Imag. 2020; 23;2: e200126.

32. Li K, Fang Y, Li W, et al. CT image visual quantitative evaluation and clinical classification of coronavirus disease (COVID-19). Eur Radiol. 2020; 30:4 407-4416.

33. Rang R, Li X, Liu H, et al. Chest CT Severity Score: An Imaging Tool for Assessing Severe COVID-19. Radiol Cardiothorac Imaging. 2020; 30; 2: e200047. 34. Colombi D, Bodini FC, Petrini M, et al. Wellaerated lung on admitting chest CT to predict adverse outcome in COVID-19 pneumonia. Radiology. 2020; 296: E86-E96. 